\title{
“Can Man Be Free If Woman Be A Slave?" A Study in Feminine Leadership in the Works of Percy Bysshe Shelley \& Bole Butake
}

\author{
George EWANE NGIDE \\ Lecturer, Department of English \\ University of Yaoundé I \\ E-mail: george_wane@yahoo.co.uk
}

Received: 13-11- 2012

Accepted: 02-01- 2013

Published: 01-03- 2013

doi:10.7575/aiac.ijalel.v.2n.2p.89

URL: http://dx.doi.org/10.7575/ijalel.v.2n.2p.89

\begin{abstract}
This article studies the primal role of female characters in the works of two dramatists separated by time and space and yet convergent in their philosophical portrayal of the woman as an agent of socio-political mutations. It posits that although Bole Butake is a Cameroonian contemporary playwright, he shares convergent views with Percy Bysshe Shelley, an English Romantic poet who also wrote lyrical dramas, in the portrayal of the front role played by female characters in bringing about change to their societies. The article concludes that though separated by culture and historical epochs, both Butake and Shelley are visionary and insightful in using women to solve the socio-political predicaments of their times.
\end{abstract}

Keywords: Feminism, Romanticism, post colonialism, comparative literature, drama, poetry

\section{Introduction}

"Can man be free if woman be a slave?" That is the rhetorical question Percy Bysshe Shelley poses in The Revolt of Islam (II, XLIII, 1). The answer of course is an emphatic no, he cannot. This is to say that the freedom and liberation of the woman is concomitant with socio-political change and that the role of the woman in bringing about such change is undeniably important, be her African, European or from any other continent deadlocked by socio-political stagnation. The fights against political corruption, malleable careerism, tyranny, despotism and monarchical rule have been a bourgeoning field of academic investigations. From time immemorial, male characters have been used in literary works as the pivot and pacesetters of such fights. Little have female characters played any substantial role in bringing about a socially and politically just society. The woman's role has hitherto been canopied to the kitchen and to other chores that are akin to her femininity, while the men do the political talking and decision-making that unfortunately also affect the voiceless woman. Oseni Taiwo Afisi, in Power and Womanhood in Africa: An Introductory Evaluation, quotes Bulkachuwa (1996: 15) as saying that:

In many areas women are still regarded as chattels to be inherited, they are given no formal education...given out in marriage at an early age. They are forever under the control of either their husbands or male relatives...they cannot inherit or own property, nor can they participate fully in public life and the decision-making process within their immediate community (235).

Even if this traditional role of the woman is fast changing and women have become more and more involved in decision-making, the quotation above brings to sharp focus the relegation of the woman to the background in matters of socio-political mutation in literary history. From British literary history, across the oceans to African literary discourse, the same female relegation in effecting and affecting socio-political change is patent and unquestionable.

\section{The Woman in African and British Literary Discourse}

\subsection{Early African Literary Discourse}

In African literary discourse, the woman is viewed as a motherhood symbol. Kenneth Little (1980), Andrea Benton Rushing (1979), Emmanuel Obiechina (1997), G.C.M Mutiso (1971) quoted by Nol Alembong (2011) have specifically examined the role and behaviour of women in various societies and the literary discourse that their treatment of women have informed. The underlying message is that women have remained the possessions of men and counted among their property. Kolawole (1997), notes that most male writers in the early phase of African literature encouraged the marginalization of women. Chukukere (1995) confirms that the ideal female character created by male writers often acts within the framework of her traditional roles as wife and mother. Fonchingong (2006) supports this notion by saying that social values are so strong that the respect and love which a woman earns is relative to her degree of adaptation to these roles. Examples abound. Chinua Achebe's Okonkwo in Things Fall Apart (1958) slaughters a goat for one of his wives who has had three sons in a row. Elechi Amadi's Madume in The Concubine (1966) is terribly discouraged and demolarised by the inability of his wife to produce a male child. Ruthven (1984) thinks that the portrayal of the female 
persona has reduced women to mere objects of voyeuristic attention only fit and portrayed through types and stereotypes, for the cinders and smoke of the literary backyards of African Literature. Ngugi's women represent the downtrodden and the pariahs in society. In I Will Marry When I Want (1980), for instance, "Two women are two pots of poison", "A woman's word is believed only after the event" and "Women cannot keep secrets". Even Tanyi-Tang's (2000) Ewa has no say in her marital home. She confirms and pathetically remarks that "we are living in a man's world". The same holds for Alobwed'Epie's (2005) Emade. She is not woman enough to be a man. In spite of the beard she wears, she remains a woman as her "urine cannot cross the beam".

\subsection{The Woman in Early British Literary Discourse}

The same indictment and marginalization of the woman is also evident in British literature. Early British Literature, from Beowulf through Chaucer, Shakespeare to some contemporary British Writers, portrays that the woman's role is less political and more muliebris, that is, in the kitchen and playing the traditional role of the woman to quote Marckwardt et al (1965). Caroline Lawrence (2008) has studied the role of women in early British literature. She holds that because "Beowulf is foundational for any study of Old English literature, its female characters are regularly the standards by which other women in Old English literature are examined." Horner (2001) had earlier considered women in this light. With most images stemming from Beowulf, women progress and digress from that point in literature. One of the more poignant figures in Beowulf, Wealhtheow, the queen of Heorot and wife to Hrothgar, is given few lines and is introduced to the audience with the obedient task of ensuring that all cups are filled with beer. According to history, the woman of the household or kingdom serviced her husband and the men of the table as the consummate hostess, keeping quiet and keeping the drink poured. The woman was thus a "dutiful slave" of the man. Christopher Marlowe in Dr. Faustus explores the image of women as the downfall of man. Helen of Troy, the greatest beauty in literary history, is used as the symbol of seduction and sin, essentially representing evil herself. Showing the striking magnetism of evil, Marlowe sees women as the ultimate temptation, the consummate sin. The female image is further marred in the works of William Shakespeare. He too writes his women to be temptations, weak and powerless. Within his plays, the female form is frail and weak as in Hamlet, taciturn, voiceless and hackneyed as in Othello or manipulative and ambitious as in Macbeth. Yet, they are romantic and innocent, like Ophelia, Desdemona, and Juliet, but led astray by their emotional desires. Historically, women are categorized as servants to men, simply to be seen and not heard. Even if Lawrence concludes her study by asserting that in literature, "the women exceed their historical counterparts and blaze trails for females to follow", this is true only recently.

Neha K. Memphis thinks that it is an indisputable fact that women have always been considered as weaker and played subservient roles to the men. Yet, women morphed from being creatures dependent on their lord, and playing merely a functional role in the story, to asserting more independence and playing a more symbolic role in the story, to actually being one of the major characters in a work of literature, elaborately developed with flaws and possible redeeming potentials. Be it as it may, the underlying premise is that female characters have developed to self independence and have assumed important roles, that of attempting to stand up to their rights and not just being subservient to the men. The assumption of such roles is, however, limited to husband/wife relationships and other feminine implications in the social development of their societies.

\section{Socio-political role of Women in Shelley and Butake}

With the advent of feminism, however, some writers have begun to give women some semblance of dominant roles. Gathoni in I Will Marry When I Want succeeds in making her own choice of a husband by contravening traditional precepts and rejecting the choice of her parents. Achebe in Anthills of the Savannahs moves from the residual and peripheral role of women in his early novels to making them play a central role in shaping and mediating the realms of power. Beatrice here champions the fight for female emancipation. That is as far as the emancipation of women can go. They have, hitherto, not been given primal political roles in the liberation of their societies from political tyranny, malleable careerism, despotism and monarchical rule by playwrights.

This article, therefore, posits that Bole Butake is the Cameroonian Percy Bysshe Shelley of female liberation of the society from socio-political misdemeanour. It stresses that although Bole Butake is a Cameroonian contemporary playwright, he shares convergent views with Percy Bysshe Shelley, an English Romantic poet, who also wrote lyrical dramas, in the front role played by female characters in bringing about change to their societies. Mboysi, Kwengong and the Kil'u women give to the liberation fight a dramatic twist by becoming violent and killing Officer and the other symbols of corruption and careerism. But even when the female characters use violence, the end of the plays reveals both Shelley's and Butake's preaching of nonviolence. The female characters in both Shelley and Butake that lead violent revolutions by using violence against violence also end up tragically or at least are warned of what Shelley calls "the fallacy of revenge". In all of Shelley's revolutionary poems and lyrical dramas, the revolutionary leaders are women: Cynthia in The Revolt of Islam; Asia in Prometheus Unbound; Mab in Queen Mab; Iona in Oedipus Tyrannus or Swellfoot the Tyrant. All are champions not only of the common people, but also of the rights of their sex. They head revolutions that defeat tyranny and monarchy. Butake on the other hand is a champion of female rights and domination in an African patriarchal traditional society. Butake's Kwengong in And Palm Wine Will Flow, the Kil'u women in Shoes and Four Men in Arms and Mboysi in The Survivors, all take up the challenge of the women liberation movement that Shelley's female characters championed in the Romantic period.

Of all the literary discourse on the empowerment of women in the Cameroonian literary landscape, only Ambanasom (2003) has come close to the main thrust of this investigation. In Education of the Deprived: Anglophone Cameroon Literary Drama, he ascertains that in Butake's dramas women have moved from their traditional backseat role of 
passive players to the foreground as a powerful force to be reckoned with if any significant social change is to take place (p.35). While Ambanasom examines the role of women in Cameroon Anglophone drama in general, we examine the role of Butake's female characters in bringing about socio-political change, comparing their action with that of the female characters of a titanic romantic poet and lyrical dramatist, Percy Bysshe Shelley. The goal here is to establish a direct link between romantic literary imagination and modern African drama, as well as points of convergence between Butake's and Shelley's empowerment of women in the struggle for socio-political freedom.

\section{Shelley and Butake in History}

Percy Bysshe Shelley was born in 1792 at Field Place, near Horsham in Sussex, England. Bole Butake was born in 1947 in Nkor, Noni Sub Division of the North West Province (now Region) of Cameroon. The one is English, the other Cameroonian. One hundred and fifty five years and thousands of kilometres separate both men. In other words both men were born into completely different cultures and in separate historical epochs. Shelley died at the prime age of 29 and today Butake is 65 . By virtue of their age difference, one will readily believe that Butake should have gained more experience in life than Shelley. Without trying to question and judge the life experiences of both men, it is evident that Butake has seen many things in life than Shelley should have, and thus schooled by life. However, Shelley at 29 seems to have been older than his age. Dismissed from Oxford at 18 for publishing a pamphlet, The Necessity of Atheism, disinherited and disowned by his own father for daring to question the existence of an omnipotent God, his early marriages and elopements, his fleeing from debtors and living a nomadic life, his personal involvement in political hotchpotch areas like Ireland, France, Spain and others, his friendships with William Godwin and Tom Paine, both of them radical philosophers, the court refusal to grant him custody of his children for reasons of his revolutionary ideas and works published, all contributed to making Shelley a man older than his age. On the eve of his anticipated death he told his friend, Thomas Jefferson Hogg, quoted by Mrs Shelley in the "Preface" to Edward Dowden's The Complete Poetical Works of Percy Bysshe Shelley that "if I die tomorrow, I have lived to be older than my father" (21). Although he was drowned mysteriously and his corpse cremated, one thing is certain, Shelley's experience about life is far reaching and his fight against oppression and repression of all forms is untainted. Does Butake have the kind of life experience that Shelley had? This is yet to be established by his biographers. From the published works of both men, however, there is reason to believe that though separated by age, culture, continent and historical epochs, both Shelley and Butake have convergent views on a number of issues. Shelley's revolutionary fervent is present in Butake's major works cited earlier. Ambanasom writes of Butake:

Whether drawing from a mythic imagination or from a contemporary social scene, Butake succeeds in making his plays scathing commentaries on contemporary social life, both in Cameroon in particular and Africa in general; especially where there is irresponsible political leadership, unconscionable dictatorial rule, rapacious greed, immorality and the misuse of power. This malpractice by the elite in control of the reins of power provokes the justified anger of the oppressed masses who advocate a change of the status quo, a protest in which women play a primordial role. (35)

Butake, like Shelley, is thus a revolutionary whose plays place the woman on the front seat of the revolution for sociopolitical change and who is influenced both by his own imaginative fertility and the social events of his time. Shelley's fertile imagination is equally unquestionable and the influence of the social and political events of his day has also had a bearing on his revolutionary lyric plays. Mary Shelley writes in Notes on Queen Mab that:

Though Shelley's first eager desire to excite his countrymen to resist openly the oppressions existent during 'the good old times' had faded with early youth, still his warmest sympathies were for the people. He was a republican, and loved a democracy... His hatred of any despotism that looked upon the people as not to be consulted or protected from want and ignorance was intense. (345)

\section{Role of Female Characters}

In his quest to establish a just society Butake, like Shelley, uses female characters as champions of the revolution. Both Shelley and Butake have specific historical affinities with women in their lives. The love relationships shared with the fair sex have had a bearing on their consideration of women. For Shelley, it was a question of love in the erotic sense of the word. Condemning marriage which he considered as legalized prostitution, Shelley practiced and preached free love cultism. His marriages and elopement testify to this fact. Butake, however, shared both a filial attachment to and a working relationship with women. In an interview with him conducted in his office on June $12^{\text {th }}, 2012$, he said, "I had two kinds of women in my life. My paternal uncle's wife who was very wicked to me and my maternal uncle's wife who was very kind to me....the first pair of shoes I wore were her shoes. She had very big legs but I would stuck papers in it and wear them". The role of the women in the northwest traditional society ${ }^{\mathrm{i}}$ has also been a motivating factor for the role women play in Butake's plays. According to him the women he has known have been "very strong women". He ascertains that if the women for instance decide that "the Fon ${ }^{\text {ii }}$ will not leave the palace he will not until he apologizes". Such women as the Kil'u women in Shoes and Four Men in Arms are examples of the kind of women Butake has met in his life. Like Shelley, his mother he said has not had such an impact on his life given that he "barely knew his mother", having been an orphan at the age of 4 .

Another issue that brings both playwrights together is the possible influences socio-political events have on their writings. Shelley's lyric dramas were influenced by the social and political events of his time. Upton Sinclair (2006) attests that Shelley's play, Oedipus Tyrannus or Swellfoot the Tyrant, is based on the history of George IV sued by his wife for divorce. As she puts it, "The odious fat lecher, King George IV, was sued for divorce by his wife, Queen 
Caroline, and it was a most horrible scandal, which Britain hardly dared to whisper" (p.2). The Devil's Walk, a poem by Shelley according to Dawson was written in 1812 by Shelley to protest the actions of the British government and harsh economic conditions in the country at the time. It emerged after the food riots in Devon where Shelley lived at that time. Prices for grain were at their highest level in 1812, there were shortages of food, and prices were inflated. Shelley attacked "a brainless King" and the "princely paunch" and "each brawny haunch" of the Prince Regent. The members of both houses of Parliament and the Church were also castigated. Political leaders and the wealthy were also attacked. The British war in Spain was similarly criticized. Other poetical works and lyric dramas and pamphlets of Shelley like Letter to Lord Ellenborough, Hellas and Prometheus Unbound were influenced by specific historical events. The same holds for Butake. Ambanasom quotes Ngugi Wa Thiongo'o as having written that "literature cannot escape from the class power struggles that shape our everyday life", intimating that a writer has no choice because he is either on "the side of the people, or the side of those social forces and classes that try to keep the people down. What he or she cannot do is to remain neutral" (p.12). Butake's plays are therefore not only the result of his fertile imagination but, like Shelley, the result of events that have occurred in the Cameroonian society in particular and elsewhere in Africa in general, to which events he gives a dramatic twist.

Shoes and Four Men in Arms recalls, indubitably, the riots of the students of the then University of Yaoundé in the early 90s asking for social and political reforms. In their protest, they created a Students' Parliament that decided on the actions to be taken against the government. On one of their meetings in the students' residential area called Bonamoussadi, they were wantonly charged by the forces of law and order. In the general commotion, many lost their shoes. The hundreds of assorted pairs of shoes where piled in a heap on the confrontational spot. The Survivors and Lake God mimic the Lake Nyos gas explosion of 1986 in the North West of Cameroon during which some 2000 people, including cattle and other animals were killed. There have been missed feelings as to the main reasons for the explosion. The survivors were evacuated from the scene of the disaster, relocated to another area where they received assorted aid from the government and friendly countries. And Palm Wine Will Flow on its part is a scathing revelation and critic of corrupt political governance, the hallmarks of many African countries, particularly Cameroon. Both Butake and Shelley thus make recourse to real life events as well as to their own imaginative muscularity.

The question as to who must have influenced the other has an obvious answer given the age difference between both writers. Whether both writers have also ever met is equally obvious. Shelley had died over a hundred years before Butake's birth. The question is whether Butake ever read Shelley's works. Butake studied in the University of Leeds in England and read British Literature in both the Universities of Yaoundé and Leeds. He certainly must have come across Shelley's works, given that the revolutionary footprints and the role of the woman to lead such revolutions propounded by Shelley are present in his dramas. In an interview accorded me, Butake acknowledges that he had read Shelley but cannot remember anything about Shelley except that "he was, I think, an Irish poet". I told him Shelley was an English poet who took the question of the Irish Independence and Catholic Emancipation as a personal challenge and travelled to Ireland where he openly addressed the people. The fact that Butake thinks of Shelley as an Irish poet is enough justification that he came across Shelley's revolutionary preachings to the Irish people found especially in his "Address to the Irish People".

\section{Women: Champions of Socio-Political Revolutions in Shelley and Butake}

The Free Encyclopedia defines Political corruption as the use of power by government officials for illegitimate private gain. Within the context of this study, we add that the misuse of government power for other purposes, such as repression of political opponents and general police brutality, tyranny and monarchical rule, are also considered political corruption. The same definition includes illegal acts by private persons or corporations directly involved with the government. An illegal act by an officeholder also constitutes political corruption. This is so because the act is directly related to his official duties and is done under colour of law or involves trading in influence. Forms of corruption vary, but include bribery, extortion, cronyism, nepotism, patronage, graft, and embezzlement. Both Shelley and Butake reveal such corruption in their works and devise means of fighting it for a just and democratic society.

Shelley's the Cenci, Oedipus Tyrannus or Swellfoot the Tyrant and The Revolt of Islam like Butake's The Survivors, And Palm Wine Will Flow and Shoes and Four Men in Arms share the same thematic concerns. The works are scathing revelations of political corruption, oppression and repression of the masses by the ruling class. In the Cenci, the young Beatrice Cenci is kept with her stepmother, Lucretia, in the appalling isolation and darkness of a forbidding castle outside the Papal States by her cruel father, Francesco Cenci, whose enormous debts and misdeeds make him unable, as well as unwilling, to support his offspring. He wants to prevent Beatrice from marrying to avoid paying a dowry. She has suitors, among them a "smooth" prelate, but is unhappily resigned to her lot until her father rapes her. With the support of her brother, Giacomo, she commands two servants, Olimpio and Marzio,to kill her father, but they waver in their resolve. She taunts them and they return to strangle the man, tossing his body below a balcony as if he had fallen. She rewards them with a bag of coins.

However, suspicions about the death are raised almost within the moment of its discovery because of the wounds on the body, bloody evidence in the bedchamber, and the apparent lack of grief in the family. Confessions are extracted by torture. Beatrice, her stepmother, Lucretia, and Giacomo are to be executed while a younger brother is forced to watch. The Pope who orders the execution justifies his act in the sense that it will serve as a lesson to other youths before all old men are murdered in their sleep. In the doleful final scene, the family accepts their fate with tenderness and courage.

Like Beatrice and her family taken hostage by a senseless regime and oppressed by the society at large, Mboysi and the other four survivors in Butake's The Survivors go through a similar humiliation. As survivors of a gas explosion, they 
are moved to a resettlement camp where they are not free to move. Hungry and thirsty, they have no food to eat and no water to drink even if the friends of their land and other benefactors have been sending them gifts of food items, clothing and drink because these are controlled by Officer. They are not also allowed to leave the camp because this will mean an end to the gifts and the end of Officer's wealth. Caught in the web, The Old One says "There is no going forward and there is no turning back". (p.60). The only language Officer uses on them is "stop! Silence! Kpo!" iii (p.65). That seems to be the language of power. They are used as instruments for the enrichment of Officer and his likes. With the children (Bolame and Tata) crying of hunger, Mboysi is advised by the Old One and Ngujoh to use her female power to get some food and drink from Officer. The wise old man tells them that "Today, women are the key to power. Even the door with seven locks on it can be unlocked by a woman" (p.65). Mboysi thus becomes the "key" that opens Officer's locked heart. He falls for her, makes love to her severally and in return gives her a few cloths, water and biscuts while he keeps the rest for himself. They realise that Officer has been "Stuffing" his "decaying stomach" and his "bulging pockets on the calamity of the people" (p.93). Mboysi cajoles Officer and takes the gun from him. After treating him as a "crawling, thieving maggot" she fires "two shots" (p.84) at Officer. He is killed but Mboysi's victory song is shortlived. She is also killed, like Shelley's Beatrice, by her oppressors, other soldiers, the likes of Officer.

The same holds for Oedipus Tyrannus or Swellfoot, The Tyrant and Butake's Shoes and Four Men in Arms, in the same light as between Shelley's The Revolt of Islam and Butake's And Palm Wine Will Flow. In Swellfoot, the tyrant opulently boasts of his power and wealth. Together with his henchmen from the church and the state namely Mammon who represents Liverpool, and Purganax who represents Lord Castlereagh, they torment and oppress the swine of Thebes who represent the masses. As the Sows put it, it was Swellfoot's "kingly will/ Us wretched swine to kill". The pigs and sows live a life of misery, poverty, hunger and even famine, while the king lives in affluence and pride. The sows and pigs feed on their own "litter", they suck "but no milk will come from the dug" and all of them are skeletal and bony. The Pigs, through the chorus, ask for better living conditions in a pleading and compassionate tone. They think that theirs is "an unhappy nation" and all they need is the barest minimum to sustain their existence. The demand of the pigs and sows is considered "sedition and blasphemy" and Swellfoot instead summons his henchmen (Jews, Solomon the court porkman, /Moses the sow-gelder, and Zephaniah/ The hog-butcher) (pp.69-71) to kill the pigs. His instructions are clear and limpid:

\author{
SWELLFOOT: \\ Out with your knife, old Moses, and spay those Sows \\ [THE PIGS RUN ABOUT IN CONSTERNATION.] \\ That load the earth with Pigs; cut close and deep. \\ Moral restraint I see has no effect, \\ Nor prostitution, nor our own example, \\ Starvation, typhus-fever, war, nor prison-- \\ This was the art which the arch-priest of Famine \\ Hinted at in his charge to the Theban clergy-- \\ Cut close and deep, good Moses.
}

Because of the suffering, hunger, humiliation and oppression incurred by the masses or the pigs, they are impatient to see the end of the brutal regime of King Swellfoot. This is why they all rally behind Iona who represents Queen Caroline. They see in her a deliverer. There is general unrest around the kingdom and reports reaching the king are that his soldiers too are becoming treasonous by joining the masses against the king:

What is still worse, some Sows upon the ground Have given the ape-guards apples, nuts, and gin, And they all whisk their tails aloft, and cry, 'Long live Iona! down with Swellfoot!

The government designs the "Green Bag" scheme to hoodwink the swine into believing that Iona is guilty of sin and thus undesirably ugly. In Act II Purganax explains to the full assembly of Public Sty that the Green Bag holds a magic potion that when sprinkled over "A woman guilty of- we all know what" (Act II, i, 83) will turn her into a hideous creature. If, however, she is innocent, the potion will turn her into an angel. This is to be the test of Iona. John Pollard Guinn in Shelley's Political Thought argues that "the bag...is really filled with the concentrated poison of slander and sealed with the seal of fraud" (p.74). But before the despots execute their treachery, Iona empties the bag on them, thus trapping evil in its own villainy. She then mounts on the Minotaur, translated as John Bull, and leads the swine, transformed into bulls, in pursuit of violent revenge on Swellfoot and his acolytes. The Queen and the swine are thus victorious and they overthrow tyranny and villainy.

Iona is like the Kil'u women in Shoes and Four Men in Arms. The military dictatorship in the play can be likened to Swellfoot's rule of England in Shelley's play. The corrupt regime led by General is involved in raping, maiming, 
killing, and looting. The leaders of the land who are against General and stage a protest march are flogged by General's men. They are called vandals, terrorists, subversives and traitors. In the face of the corrupt regime, a group of old women with "long bamboos" (p.138) intervene to bring an end to the generalized looting. Their voices are heard off stage beckoning on the soldiers to come and make love to them since that seems to be the soldiers' favourite sport. They say in pidgin:

Voices: Wusa dem dey? Shoes! Shoes! Shoes! Wuna come take shoes. Wuna come take lass. Shoes! Lass! Shoes! Lass! Wuna come take shoes. Wuna come take lass!

Voices: Where are you? Shoes! Shoes! Shoes! You come and get the shoes. Come and have sex with us! Shoes! Sex! Shoes! You come and get the shoes! Come and have sex with us! (My translation)

These are the Kil'u women. The soldiers understand what it means for old women to expose their nakedness "before your eyes". They are described by Third soldier as a "kind of Mountain of elephants and a "Sleeping volcano" (p.138). He contends that the Kil'u women are reacting mostly because the opposition leaders, Kwifon and Manjong were "whipped". The pronouncements of Kil'u he says are "Law in the land. If kil'u says today ...nobody's nose should smell the outside air, that is law" (p.139). In the end, even the troops join the striking and downtrodden people. They agree to abandon "the wanton violence against others that was [their] way of life". They vow to henceforth respect "basic rights of each and every individual" (p.142).

\section{Conclusion}

The plays studied so far reveal the important revolutionary role that the female characters of both Shelley and Butake play to bring about a just and harmonious society. Mboysi in the Survivors uses bottom power to save the men from hunger and thirst. She is Butake's revolutionary symbol in the same light as Shelley's Beatrice in the Cenci story. Both female characters undergo sexual harassment. It is because they are sexually abused that they are encouraged to take revenge in order to satisfy, first, their own vengeful zeal and second save the people with whom they suffer the same fate of marginalisation by the ruling class. Shelley's Iona in Swellfoot, the Tyrant is the same as Butake's Kil'u women. They are witnesses of the corrupt military dictatorships of their various societies. Like Iona who leads the pigs and sows in a revolution that overthrows the regime, the Kil'u women put an end to the military dictatorship in Butake's Shoes and Four Men in Arms. The Kil'u women like Shelley's Iona are not killed in the respective plays whereas Mboysi and Beatrice are killed by the henchmen of those they kill.

The message that Shelley and Butake are transmitting is not just that nonviolence is necessary in a revolution because a violent revolution leads to more violence, but that where a violent revolution becomes inevitable, there is need for organisation. Shelley thinks that violence begets violence and the tragic circle of violence continues even if the regime changes. This is what he calls "the fallacy of revenge". Butake says that "the problem I have with Mboysi, even though I created her is that she did not prepare her revolution, she was thinking of her personal revenge" (interview with Butake).

Though separated by cultural and historical epochs, therefore, both Butake and Shelley are visionary and insightful in using women to solve the socio-political predicaments of their times. They use both violent and nonviolent female characters. They both make the violent characters lose their lives as a way of condemning violence. The societies that they establish at the end of their plays are democratic and the leaders are chosen by the people.

\section{References}

Achebe, C. (1980). Arrow of God. London: Heinemann.

Afisi, O. T. (2010). "Power and Womanhood in Africa: An Introductory Evaluation" The Journal of Pan-African Studies. Vol 3, No 6 (March 2010): 229-238.

Alobwed'Epie, C. (2005). The Lady With A Beard. Yaoundé: Editions Clés.

Amadi, E. (1966). The Concubine. London: Heinemann

Ambanasom, S. (2003). Education of the Deprived: A Study of Four Cameroonian Playwrights. Yaoundé: Presses Universitaires de Yaoundé.

Alembong, N. (2011). "Femininity in Cameroonian Birth and Nuptial Songs" Kaliao. Vol 3, Number 5: 113-125.

Bulkachuwa, Z. (1996). "The Nigerian Woman: Her Rights and Obligations”. Women Herald. Vol 8: 15-17.

Butake, B. (1999) Lake God and Other Plays. Yaoundé: Editions Clés.

Beowulf and Other Old English Poems. (1988). Trans. Constance B. Hieatt. New York: Bantam Books.

Brown, L. (1993). Ends of Empire: Women and Ideology in Eighteenth-Century English Literature. New York: Cornell University Press.

Chukukere, G. (1995). Gender voices and Choices: Redefining Women in Contemporary African Fiction. Enugu, Nigeria: Fourth Dimension Publishing.

Dowden, E. (1893). The Complete Poetical Works of Percy Bysshe Shelley. New York: Thomas Y. Crowell \& Co. 
Fonchingong, C. C. (2006) "Unbending Gender Narratives in African Literature" Journal of International Women's Studies. Vol 8, No 1: 135-147.

Horner, S. (2001). The Disclosure of Enclosure: Representing Women in Old English Literature. Albany: New York University Press.

Kolawole, M. E. M. (1997). Womanism and African Consciousness. Trenton, NJ: Africa World Press.

Little, K. (1980). The Sociology of Urban Women's Image in African Literature. New Jersey: Rowman.

Mutiso, G.C.M. (1971) "Women in African Literature”. East African Journal, 3: 3, 4-14.

Ngugi, W., \& Ngugi, W. M. (1980). I Will Marry When I Want. London: Heinemann.

Obiechina, E. (1997) "Feminine Perspectives in Selected African Novels". Nwanyibu: Womanbeing \& African Literature, eds. Phanuel Akabueze Egejurn and Ketu H. Katrak, Trenton, NJ: Africa World Press, 33-46.

Rushing, A. (1979). "Images of Black Women in Modern African Poetry: An Overview". Sturdy Black Bridges, eds. Roseann P. Bell et al. New York: Anchor Press/ Doubleday. 18-24.S

Ruthven, K. (1984). Feminist Literature Studies: An Introduction. United Kingdom: Cambridge University Press.

Tanyi-Tang, Anne (2000). Ewa and other Plays. Yaoundé: Editions Clés.

\section{Notes}

${ }^{\mathrm{i}}$ The Northwest is one of the ten regions of Cameroon, a country of about twenty million inhabitants in Central Africa.

ii The Fon is the supreme traditional ruler in the Northwest traditional society of Cameroon. He is the custodian of the values of the society. At the national level he is the equivalent of the President of the Republic. He therefore has powers given to him by the people but which powers are sometimes misused.

iii "Kpo" is an onomatopoeic sound that mimics the sound of the gun. 